Dunamis: Jurnal Teologi dan Pendidikan Kristiani

Volume 2, Nomor 2 (April 2018)

ISSN 2541-3937 (print), 2541-3945 (online)

http://www.sttintheos.ac.id/e-journal/index.php/dunamis

Submitted: 20 Februari 2018

Accepted: 22 April2018

Published: 23 April 2018

\title{
Analisis Historis terhadap Teologi Gerakan Pentakostalisme
}

\author{
Daniel Sutoyo \\ Program Magister Teologi Sekolah Tinggi Teologi Intheos Surakarta \\ danielsutoyo@gmail.com
}

\begin{abstract}
The purpose of this paper is to explain the historical developments, doctrines and behaviors that appear in every Pentecostal movement, so that we can distinguish between the First Wave movement, the Classical Pentecost, the Second Wave Movement, the Charismatic Movement, the Third Wave Movement, the Sign Movement and the Miracles, and Fourth Wave Movement, New Apostolic Reformation Movement (NAR). The method in this study is the study of historical analysis on the history of the development of each wave movement Pentecostalism. Through the analysis it is concluded that every wave of the Pentecostal movement is a movement that comes from God, through the work of His Holy Spirit. Although in practice there is a distorted phenomenon, but can not be generalized and then assume everything is heretical.
\end{abstract}

Keywords: the pentecostal movement; a charismatic movement; Pentecostalism; signs and miracles; the Holy Spirit

\begin{abstract}
Abstrak
Tujuan penulisan ini adalah menjelaskan sejarah perkembangan, doktrin dan perilaku yang muncul setiap gerakan Pentakostalisme, sehingga kita dapat membedakan antara gerakan Gelombang Pertama, Pentakosta Klasik, Gerkan Gelombang Kedua, Gerakan Kharismatik, Gerakan Gelombang Ketiga, Gerakan Tanda-tanda dan Mujizat-mujizat, dan Gerakan Gelombang Keempat, Gerakan New Apostolic Reformation (NAR). Metode dalam penelitian ini adalah penelitian analisis historis terhadap sejarah perkembangan setiap gerakan gelombang Pentakostalisme. Melalui analisis tersebut disimpulkan bahwa setiap gelombang gerakan Pentakostalisme adalah sebuah gerakan yang berasal dari Tuhan, melalui karya Roh Kudus-Nya. Meskipun dalam praktiknya ditemukan fenomena yang menyimpang, namun tidak dapat digeneralisasikan dan kemudian menganggap semuanya sesat.
\end{abstract}

Kata kunci: gerakan pentakosta; gerakan kharismatik; Pentakostalisme; tanda dan mujizat; Roh Kudus

\section{PENDAHULUAN}

Gerakan Pentakostalisme pada abad

ke 20 merupakan kelanjutan gerakan Roh

Kudus pada gereja mula-mula dalam Kisah
Para Rasul. Gerakan Pentakostalisme dengan pencurahan Roh Kudus dengan cara yang baru "merupakan pemenuhan 
nubuatan akhir zaman." Seperti yang pernah dilakukan Rasul Petrus pada perkembangan gereja mula-mula yang terjadi hampir 2000 tahun, yaitu pada hari raya Pentakosta (Kis. 2:16-21), gerakan Pentakostalisme terus berlanjut sepanjang abad ke-20 untuk melanjutkan pemberitaan dari nabi Yoel (Yl. 2:28-32) dan gerakan Pentakostalisme pada gereja mula-mula.

Apresiasi terhadap makna dan fungsi yang melekat pada nubuatan nabi Yoel dan gereja mula-mula adalah kunci yang penting untuk memahami perkembangan gerakan Pentakostalisme pada permulaan milenium ketiga ini. Meskipun glossolalia (bahasa lidah) merupakan faktor yang sering diidentifikasi secara khas untuk membedakan gerakan kekristenan lainnya, telah menjadi subyek studi ilmiah, nubuat selalu menjadi bagian integral dari kepercayaan dan praktik gerakan Pentakostalisme. Memang pada umumnya bahwa setiap gerakan Pentakostalisme menekankan dalam hal tertentu sebagai tanda untuk membedakan dari gerakan ke gerakan berikutnya. Setiap gerakan Pantekostalisme mempunyai teologi dan iman yang beragam, mungkin secara fenomenologis sangat sulit untuk

\footnotetext{
${ }^{1}$ DJ Wilson, "Pentecostal Perspectives on Eschatology," in Dictionary of Pentecostal and Charismatic Movements, ed. Stanley M. Burgess and Gary B. McGee (Grand Rapids: Zondervan Publishing House, 1998), 264-268.
}

dibedakan, karena gerakan-gerakan Pentakostalisme merupakan pengalaman adikodrati, termasuk glossolalia (berbicara dalam bahasa roh), penyembuhan, pembebasan setan, mujizat dan nubuatan dan lainnya.

Menurut DeArteaga gerakan Pentakostalisme selama abad ke-20 telah menyebar melalui kegiatan para misionaris yang ekstensif. ${ }^{2}$ Gerakan Pentakostalisme merupakan gerakan kekristenan yang dinamis, karena gerakan Pentakostalisme telah menyusup ke dalam gereja Katolik dan beberapa gereja Protestanisme aliran utama (mainstream) lainnya. Beberapa aliran Pentakostalisme klasik sekarang lebih besar dari beberapa denominasi gereja arus utama, sementara beberapa gereja kharismatik independen dan nondenominasional yang tak terhitung jumlahnya telah berperan dalam reinvention of Protestantism ${ }^{3}$ Gerakan Pentakostalisme (termasuk arus kharismatik (gelombang kedua) dan gerakan tanda-tanda dan mujizat (gelombang ketiga) dikatakan mewakili satu dari empat orang Kristen di seluruh

\footnotetext{
${ }^{2}$ William DeArteaga, Quenching the Spirit (Lake Mary, FL: Creation House, 1992), 102.

${ }^{3}$ Donald E. Miller, Reinventing American Protestantism (Berkeley: University of California Press, 1997), 56.
} 
dunia, melintasi batas-batas keagamaan dan juga wilayah geografis. ${ }^{4}$

Pemahaman yang baik dan objektif terhadap gerakan-gerakan Pentakostalisme secara historis tidak muncul dengan tibatiba begitu saja. Sebab dalam sejarah gereja sejak abad 2 Masehi telah ada cikal bakal gerakan Pentakostalisme (Montanisme) dan terus melaju ke abad Pietisme, Metodisme, Gerakan Kekudusan, Pentakostalisme Klasik (awal abad XX), dan Pentakostalisme Baru atau Kharismatik (tahun 1960-an), Kharismatik Baru atau Gelombang Ketiga (1980 sekarang), bahkan memungkinkan munculnya gelombang keempat.

\section{Pembatasan Masalah}

Pembahasan dalam tulisan ini hanya dibatasi pada evaluasi kritis terhadap sejarah perkembangan, ajaran dan para tokoh yang mengembangkan gerakan Pentakostalisme setiap gelombang, yaitu Gerakan Gelombang Pertama, Pentakosta Klasik, Gerakan Gelombang Kedua, Gerakan Kharismatik, Gerakan Gelombang Ketiga, Gerakan Tanda-tanda dan Mujizatmujizat, dan Gerakan Gelomang Keempat, Gerakan New Apostolic Reformation (NAR). Setiap gelombang mempunyai doktrin dan perilaku yang berbeda antara

\footnotetext{
${ }^{4}$ David B. Barrett, ed., World Christian Encyclopedia (New York: Oxford University Press, 1982), 70.
}

satu dengan yang lain, yang memungkinkan fenomena yang muncul kepermukaan mempunyai kesamaan, karena semua gelombang menekankan pada yang sama yaitu pneumatologis.

\section{Tujuan Penelitian}

Tujuan penulisan ini adalah menjelaskan sejarah perkembangan, doktrin dan perilaku yang muncul setiap gerakan Pentakostalisme, sehingga kita dapat membedakan antara gerakan Gelombang Pertama, Pentakosta Klasik, Gerkan Gelombang Kedua, Gerakan Kharismatik, Gerakan Gelombang Ketiga, Gerakan Tanda-tanda dan Mujizat-mujizat, dan Gerakan Gelomang Keempat, Gerakan New Apostolic Reformation (NAR). Gerakan gelombang demi gelombang tersebut berasal dari Allah yang dikerjakan oleh Roh Kudus, maka gerakan gelombang-gelombang Pentakostalisme merupakan gelombang Roh Kudus.

\section{Gelombang-Gelombang dalam Gerakan} Pentakostalisme

Gerakan Pentakostalisme Gelombang Pertama: Pentakostalisme Klasik

Pentakostalisme klasik adalah yang pertama dari tiga gelombang (bahkan empat gelombang) yang dikelompokkan pengamat sebagai pencurahan Roh Kudus di zaman akhir. Pada umumnya gerakan gelombang pertama diidentifikasikan 
gerakan Pentakostalisme dengan glossolalia, yang implikasinya adalah gerakan Roh Kudus yang berasal dari awal abad ke-20, di sebuah sekolah tinggi Alkitab yang kecil di Topeka, Kansas di bawah kepemimpinan seorang pengkhotbah Kekudusan, yaitu Charles F. Parham pada tahun 1900, atau peristiwa pentakosta pada tahun 1906 di Black Mission di Azusa Street, Los Angeles di bawah kepemimpinan William J. Seymour. Keduanya berasal dari latar belakang Gerakan Kekudusan dan dipengaruhi oleh teologi Arminian.

Di awal tahun 1900, Parham mendirikan Bethel Bible School of Topeka, di Kansas dan menjelang akhir bulan Desember 1900, Parham meminta para siswa-siswinya untuk menyelidiki Alkitab guna menjawab apakah bukti atau tanda alkitabiah dari seseorang yang dibaptis Roh Kudus. Ketika Parham pergi selama tiga hari untuk pelayanan, murid-muridnya bersama-sama berdoa, berpuasa dan mempelajari Alkitab. Ketika kembali dari pelayanan, Parham mendengar jawaban dari para muridnya bahwa bukti alkitabiah dari seorang yang dibaptis oleh Roh Kudus adalah orang tersebut berbicara dalam Bahasa Roh. ${ }^{5}$ Mereka sungguh-sungguh menantikan urapan dan baptisan

\footnotetext{
${ }^{5}$ Gani Wiyono, Gereja Sidang-Sidang Jemaat Allah Dalam Lintasan Sejarah 1936-2016 (Malang: Gandum Mas, 2016), 3.
}

Pentakosta. Hingga pada pergantian tahun, 1 Januari 1901, salah satu murid Parham yang bernama Agnes N. Ozman berbicara dalam bahasa lidah selama tiga hari lamanya ia berbicara dan menulis dalam bahasa yang tak pernah ia pelajari sebelumnya. ${ }^{6}$ Dua hari kemudian tanggal 3 Januari 1901 dalam pertemuan doa petang, siswa-siswi yang lainpun mengalami Baptisan Roh Kudus dan berbicara dalam bahasa-bahasa lain. Parham yang masuk ke ruangan doa pada petang itupun tergugah untuk mengalami pengalaman serupa. Pada malam itu Parham mengklaim telah mendapatkan Baptisan Roh Kudus.

Pada tahun 1903 Parham diundang untuk melayani KKR di Galena Kansas. Dalam KKR ditandai dengan kesembuhan ilahi yang menarik perhatian ribuan orang bahkan orang-orang dari tempat-tempat yang jauh. Pada saat itu banyak orang mengalami Pentakosta yang ditandai dengan bukti secara fisik bahasa lidah asing. ${ }^{7}$ Di sinilah awal munculnya dogma bahwa bahasa lidah (glossolalia) adalah bukti pertama dari baptisan Roh Kudus. Maka mulailah Parham menjadikan peristiwa ini sebagai inti khotbahkhotbahnya di dalam ibadah-ibadah. Ia menentang paham bahwa karunia rohani

\footnotetext{
${ }^{6}$ Ibid, 4.

${ }^{7}$ Ibid.
} 
supranatural sudah berhenti bersama dengan wafatnya para rasul.

Puncak popularitas Parham pada pertengahan tahun 1906 dengan kira-kira 8.000-10.000 orang pengikut setia. Gerakan Pentakostalisme ini dilanjutkan oleh William Joseph Seymour yang bertumbuh dan berkembang dengan spektakuler. Seymour adalah mantan murid Parham yang pernah mendengar pengajaran Parham hanya dari luar ruang kelas, karena berkulit hitam yang tidak dapat bersama-sama dengan orang berkulit putih dalam satu ruangan. Setelah mendapat pengajaran dari Parham, kemudian Seymour mengadakan kebangunan rohani dengan meggunakan bangunan di Jalan Azusa, California yang selanjutnya terkenal dengan Azusa Street Mission. Pada tanggal 6 April 1906, Seymour memimpin jemaat di Bonnie Brae Street untuk melakukan doa puasa selama 10 hari. Focus dari doa puasa ini adalah jelas, yaitu supaya terjadi kebangunan rohani seperti di Wales (1904). Tiga hari kemudian pada tanggal 9 April 1906 ia berkhotbah tentang baptisan Roh Kudus (Kis. 2:4), sebelum selesai berkhotbah terjadi baptisan Roh Kudus seperti "api dari sorga" turun seperti pada hari Pentakosta pertama di jemaat di Bonnie Brae Street. Banyak anggota jemaat yang mengalami ekstasi dan berkata-kata dalam bahasa lidah. Peristiwa ini sebenarnya awal dari kebangunan rohani Azusa Street. ${ }^{8}$

Koran Los Angeles Times edisi tanggal 18 April 1906 menyebutkan ibadah tersebut sebagai Weird Babel of Tongues (ucapan yang tidak jelas dan tidak alami). Selama ibadah-ibadah berjalan kadang polisi menutup jalan tersebut dan banyak orang yang minta ibadah tersebut ditutup karena mengganggu lingkungan, bahkan tidak diterima oleh gereja-gereja lain dan ada juga yang berasal dari gereja Pantekosta. Jennie Moore ketika kembali beribadah di gerejanya di First New Testament Church dan berbahasa roh di sana akhirnya ia tidak diterima. Phineas Bresee dari Pentacostal Church of Nazarene juga menentang ibadah tersebut dan mencapnya sebagai False Revival. Bresee menurunkan tulisan tentang Pantekostalisme di mana pentakosta di gerejanya agar tidak dihubung-hubungkan dengan kejadian di Azusa Street. Pemimpin Pentacostal Union Church, bishop Alma White menuduh Azusa Revival tersebut sebagai penyembahan setan dan mempratekkan okultisme dan penyelewengan seksual. ${ }^{9}$ Sekalipun banyak dikecam, namun Azusa Street Revival telah menghadirkan dalam pertemuan ibadah

\footnotetext{
${ }^{8}$ Ibid, 7.

${ }^{9}$ Ibid.
} 
dari banyak golongan dan tingkatan yang dimulai dari yang berpendidikan, tidak berpendidikan, kaya, miskin, dari Afrika, Asia, kulit putih, hitam dan warga asing. Frank Bartleman melukiskan kejadian itu sebagai "The color line was washed in the blood." 10

Dalam ibadah tersebut baik semua anggota jemaat, baik mereka yang berkulit putih, laki-laki dan perempuan, pendeta, penginjil dan jemaat asing terlibat dalam kepemimpinan ibadah. Sering terjadi banyak warga asing bertobat karena beberapa jemaat ketika dipenuhi Roh Kudus dan berbicara dalam bahasa mereka. Sebenarnya mereka masih di bawah denominasi gereja mereka dan menyebarkan teologi baru, yaitu Pantekosta tesebut ke dalam gereja mereka. Pola dari Azusa Street Mission menghendaki bahwa Roh Kudus tidak hanya untuk memimpin para leader gereja, tetapi untuk semua orang-orang percaya bebas berbicara selama ibadah itu. Mereka mengajarkan Roh Kudus tidak boleh dibatasi oleh gedung gereja, tetapi menyebar ke dalam bentuk kesaksian baik di jalan ataupun di dalam pekerjaan mereka.

Selain gerakan ini mengalami Bahasa Roh beberapa laporan menceritakan juga terjadi visi dan

\footnotetext{
${ }^{10} \mathrm{Ibid}$
}

fenomena luar biasa yang sebelumnya tidak pernah dipelajari. Sehari ibadah bisa sembilan kali, mulai dari pagi sampai larut malam. Mereka bisa mulai ibadah sendiri tanpa perlu ada pemimpin. Kadang-kadang tidak ada program yang harus dijalankan tetapi mereka tidak takut karena Roh Kudus mampu mengendalikan kebaktian itu.

Albert Benjamin Simpson sangat terlibat dengan gerakan Pentakostalisme yang berkembang pesat. Pada saat itu para pendeta dan misionaris Pentakostalisme biasanya dilatih di Missionary Training Institute yang didirikan oleh Simpson. Karena itu, Simpson dan CMA (sebuah gerakan penginjilan yang didirikan oleh Simpson) yang sangat berpengaruh terhadap gerakan Pentakostalisme, khususnya gereja-gereja Sidang Jemaat Allah dan Foursquare Church. Pengaruh ini mencakup penekanan pada penginjilan, doktrin CMA, nyanyian-nyanyian dan buku-buku karya Simpson, dan penggunaan istilah “Tabernakel Injil” yang berkembang menjadi gereja-gereja Pentakosta yang dikenal sebagai "Tabernakel Injil Sepenuh."

Gerakan ini dengan cepat menyebar ke seluruh wilayah Amerika Serikat dan negara-negara lain. Menurut data, pada tahun 1972 pengikut aliran Pentakosta di seluruh dunia sudah mencapai 20 juta 
orang. Gereja Pentakosta mempunyai ciriciri yang sama di seluruh dunia, antara lain: kebaktian yang serba bebas, pemakaian Alkitab secara spontan, pembangunan jemaat melalui kegiatan kebangunan-kebangunan rohani yang meliputi dorongan untuk bertobat dan hidup suci, dan anggapan bahwa dalam lingkungan jemaat perlu ada karunia lidah dan karunia kesembuhan sebagai tandatanda orang percaya.

Secara teologis, gereja-gereja yang bergabung dengan gerakan Pentakostalisme ini mempunyai teologi evangelikalisme, artinya mereka menekankan bahwa Alkitab itu sepenuhnya firman Allah yang dapat dipercaya, hingga pada tingkat ineransi (Alkitab tidak mengandung kesalahan) dan orang harus bertobat dan percaya kepada Yesus. Pengikut gerakan Pentakostalisme berbeda dengan orang Fundamentalis karena mereka lebih menekankan pengalaman rohani pribadi.

Gerakan Pentakostalisme biasanya memiliki pandangan dunia yang transrasional. Meskipun mereka sangat memperhatikan ortodoksi (keyakinan yang benar), mereka juga menekankan ortopati (perasaan yang benar) dan ortopraksis (refleksi atau tindakan yang benar). Penalaran dihargai sebagai bukti kebenaran yang sahih, tetapi orang-orang
Pentakostalisme tidak membatasi kebenaran hanya pada ranah nalar. Jackie David Johns dalam bukunya tentang kepemimpinan formatif Pentakosta, menyatakan bahwa Alkitab mempunyai tempat yang khusus dalam pandangan dunia Pentakostalisme karena Roh Kudus selalu aktif di dalam Alkitab. Bagi Johns, pertemuan dengan Alkitab adalah pertemuan dengan Allah. Bagi orang Pentakostalisme, Alkitab adalah referensi utama bagi persekutuan dengan Allah dan pedoman untuk memahami dunia. ${ }^{11}$

Salah satu ciri paling utama yang membedakan Pentakostalisme dengan Evangelikalisme adalah penekanannya pada karya Roh Kudus. Bahasa Roh yang juga dikenal dengan glossolalia, adalah bukti normatif dari baptisan Roh Kudus. ${ }^{12}$ Beberapa gereja Pentakostalisme utama (klasik) juga meyakini bahwa mereka yang tidak berbahasa Roh belum menerima berkat yang mereka namakan baptisan Roh Kudus. Klaim ini unik bagi kaum Pentakostalisme dan merupakan salah satu dari sedikit perbedaannya dengan teologi Kharismatik.

\footnotetext{
11 "Pentakostalisme - Gereja Pentakosta PUSTAKA BERBAHASA INDONESIA Sejarah.stt-Mandala.web.id," accessed April 17, 2018, http://sejarah.stt-mandala.web.id/ind/25152408/Pentakostal_30764_stt-mandala_sejarah-sttmandala.html.

${ }^{12}$ Ibid.
} 
Gerakan Pentakostalisme Gelombang

\section{Kedua: Kharismatik}

Suatu kesulitan untuk menentukan kapan waktunya dan di mana tepatnya gerakan Pentakostalisme gelombang kedua Kharismatik mulai muncul sebagai gerakan yang berpengaruh di antara mainstream churches (gereja-gereja aras utama). Istilah kharismatik berasal dari kata Yunani charisma (bentuk jamaknya adalah charismata yang berarti karunia-karunia), yang berarti karunia Roh. ${ }^{13}$ Gerakan Pentakostalisme gelombang kedua, kharismatik kini bermula pada dan mempunyai banyak persamaan dengan gerakan Pentakostalisme Klasik. ${ }^{14}$ Pengalaman rohani tertentu yang dianggap sebagai ciri utama gerakan Pantekostalisme adalah "Baptisan Roh" dan "karunia-karunia Roh Kudus" seperti yang dilakukan oleh Full Gospel Bussines men's Fellowship International (FGBFI) yang merupakan kelompok bussinesmen (para pengusaha) yang mempunyai misi, salah satunya adalah menolong orang percaya agar mendapatkan baptisan Roh Kudus dan mengalami pertumbuhan rohani. $^{15}$

\footnotetext{
${ }^{13}$ Jan S. Aritonang, Berbagai Aliran Di Dalam Dan Di Sekitar Gereja (Jakarta: BPK Gunung Mulia, 2003), 197.

${ }^{14}$ Ibid, 196.

${ }^{15}$ A. Van Kooij and Yam'ah Tsalatsa A, Bermain Dengan Api: Relasi Antara Gereja-Gereja
}

Gerakan

Pentakostalisme gelombang kedua ini pada umumnya dipelopori oleh Demos Shakarian (1953) yang didukung oleh David J. du Plussis yang mempelopori hubungan Kharismatik dengan Dewan Gereja-Gereja se Dunia (DGI) dan gerakan oikomenikalisme. Demos Shakarian, adalah seorang petani jutawan dengan latar belakang Pentakostalisme, adalah pelopor lahirnya gerakan Kharismatik ini. Shakarian mengalami baptisan Roh Kudus pada usia 13 tahun pada tahun 1926, yang disertai dengan kesembuhan pada telinganya. Ia bekerja sama dengan Charles S. Price setelah kesembuhan adiknya, yang mengalami kecelakaan fatal, melalui penumpangan tangannya. Kerinduaannya adalah mendukung segala upaya untuk kebaktian-kebaktian kebangunan rohani. Pada tahun 1951, ia mengatakan kerinduannya untuk membentuk FGBMFI kepada Oral Robert. Allah meneguhkan kerinduannya itu melalui penglihatan.

Peristiwa bersejarah itu diawali dengan pertemuan Morning Breakfast antara Shakarian dengan Oral Roberts dalam suatu konvensi nasional perdana para pelayan kesembuhan ilahi tahun 1953, dimana Oral Roberts menjadi pembicaranya. Dari pertemuan ini lahirlah

Mainstream Dan Kalangan Karismatik Pentakosta (Jakarta: BPK Gunung Mulia, 2007), 34. 
FGBMFI, yang akhirnya berkembang menjadi pertemuan konvensi berskala besar (se-dunia), suatu organisasi pengusaha Kristen yang dipenuhi Roh Kudus dan pengalaman berbahasa Roh. Misi mereka adalah bersaksi kepada orang Kriten non-Pentakostalisme dengan sarana majalah bulanan mereka yang bernama Voice. Pada tahun 1953 FGBMFI menyebut diri sebagai organisasi bisnismen yang dipenuhi Roh Kudus dan terpanggil melaksanakan penginjilan dan kesasksian kepada umat nonPentakostalisme, mereka sering menggunakan istilah "persekutuan kharismatik." 16

Tokoh penting lainnya dalam gerakan ini adalah Dennis J. Bennet, seorang pendeta Episkopal (Anglikan) di Los Angles (tahun 1960). ${ }^{17}$ Dennis J. Bennet, adalah orang ketiga yang berperan besar dalam kelahiran gerakan Pentakostalisme gelombang kedua, Kharismatik ini. Semula ia melayani di gereja Kongregasional sejak tahun 19491950 di San Diego, California. Tetapi kemudian tahun 1951, ia menjadi vikarius di Paul's Episcopal Church, serta menjadi imam tahun 1952, dan ia menjabat pimpinan di Mark's Episcopal Church di

\footnotetext{
${ }^{16}$ Aritonang, Berbagai Aliran Di Dalam Dan Di Sekitar Gereja, 198.

17 "Pentakosta Dan Kharismatik," in Makalah Sahabat Awam (Bandung: Yayasan Bina Awam, n.d.), 7.
}

Van Nuys (1953). Bennet yang pertama kali mengumumkan pengalaman kharismatisnya di hadapan anggota jemaat gereja lokalnya di Van Nuys yang menyebabkan dirinya dipecat tahun 1959 . Setelah ia dipecat dari gereja tersebut karena mengalami baptisan Roh Kudus, ia ditawari menggembalakan di gereja St. Luke, gereja yang nyaris ditutup karena mengalami kemunduran. Akhirnya gereja ini menjadi pusat penyebaran gerakan Pentakostalisme gelombang yang kedua, yaitu Kharismatik di seluruh Amerika. Ia juga mendirikan Episcopal Charismatic Fellowship dan Christian Association. ${ }^{18}$ Jadi dapat dikatakan bahwa, awal publikasi kelahiran Gerakan Pentakostalisme Gelombang kedua, Kharismatik ini dimulai di kalangan Episkopalian tahun 1959, saat John dan Joan Baker mengalami baptisan Roh Kudus dengan tanda bahasa roh, disusul oleh Dennis Bennet dan Frank Maguire pada tahun yang sama, bersama dengan beberapa orang dari persekutuanpersekutuan doa di Moneterey Park dan Van Nuys, St. Luke, dan persekutuan yang disertai nubuat dan penafsiran bahasa roh. Pada Oktober 1962, fenomena glossolalia terjadi di Universitas Yale, bagi para anggota Evangelical Inter-Varsity

\footnotetext{
${ }^{18}$ Aritonang, Berbagai Aliran Di Dalam Dan Di Sekitar Gereja, 203-2016.
} 
Christian Fellowship. Gerakan

Kharismatik terdiri dari orang-orang Episkopal, Lutheran, Presbyterian, Methodist dan bahkan orang-orang Katholik Roma. Setelah itu, gerakan ini mulai menyebar ke Universitas Dartmouth, Universitas Stanford, dan Seminari Teologi Princeton. ${ }^{19}$ Kemudian pada tahun 1966, Gerakan Kharismatik menembus masuk ke Gereja Katholik Roma dimana secara mudah ia diterima oleh masyarakat awam dan rohaniwan terbuka melalui Konsili Vatikan II, terhadap ide-ide baru terhadap pembaruan gereja. Gerakan Kharismatik ini berbeda dengan Pentakostalisme Klasik dalam beberapa fenomena, termasuk penolakan terhadap perlunya berbicara dalam bahasa roh sebagai tanda bahwa telah dibaptis oleh roh. ${ }^{20}$ Kemudian sejak sekitar tahun 1975 , Gerakan Kharismatik ini tampaknya dipengaruhi oleh Gerakan Hujan Akhir (Later Rain Movement) dan para pengajar dari Gerakan tersebut, seperti William M. Branham, Reginald Layzel, James Beall,

\footnotetext{
${ }^{19}$ David C. Forsyth, "History of the Charismatic Movement," accessed April 17, 2018, http://www.christianfallacies.com/articles/forsyth/hi storyOfCharismaticMovement.html.

${ }^{20}$ Steve Durasoff, Bright Wind of the Spirit:

Pentecostalism Today (U.S: Prentice-Hall, n.d.), 191.
}

Ray Jacson, Ralp Mahoney, Dick Iverson, dan Kevin J. Conner. ${ }^{21}$

Pada tahun 1980-an FGBMFI telah berhasil membentuk sekitar 2.500 cabang atau kelompok yang aktif dan tersebar di seluruh dunia. Anggotanya adalah kalangan menengah ke atas, seperti direktur, pengacara, dokter, kontraktor, pedagang besar dan mahasiswa atau kaum muda karier. Dengan corak keanggotaan seperti itu wajarlah di dalamnya ditekankan "kemakmuran sebagai berkat Allah" atau yang sering dikenal dengan "Teologi Sukses."

Secara singkat ajaran pokok dari gerakan Pentakostalisme gelombang kedua, gerakan Kharismatik antara lain; 1) Berpusat pada Kristus, artinya pengalaman baptisan Roh Kudus secara konstan mengalami perjumpaan dengan Kristus, penyerahan total kepada Yesus, dan penerimaan Yesus sebagi Tuhan. 2) Kuasa Rohani, artinya kaum Kharismatik menerima kuasa rohani ketika mengalami baptisan Roh Kudus, sebab Roh Kudus memberi kuasa (dynamis) untuk mengusir setan, menyembuhkan, berani memberitakan Injil, mempraktekkan karunia-karunia. 3) Pujian dan penyembahan, akibat baptisan Roh Kudus secara langsung adanya luapan pujian dan

\footnotetext{
${ }^{21}$ Dick Iverson, "Kebenaran Masa Kini," in Tongkat Gembala (Jakarta: Lembaga Pusat Hidup Baru, 1994), 132.
} 
penyembahan karena penuh Roh Kudus. 4) Komunikasi langsung dengan Tuhan, kaum Kharismatik dalam persekutuan maupun pribadi yang sering mengungkapkan bahwa Allah berbicara kepadanya, sebab orang yang mengalami baptisan Roh Kudus dapat mendengar suara Tuhan dan dapat berkomunikasi dengan Tuhan. 5) Karunia-karunia Roh Kudus, ciri-ciri gerakan Kharismatik adalah karunia-karunia Roh (charismata), yang oleh kaum kharismatik menekankan glosolalia, nubuat, dan penyembuhan. 6) Peperangan rohani, menurut Ed Murpy seorang wakil presiden dan direktur dari International Ministry Team of Overseas Crusades menyatakan bahwa tiga penjelasan peperangan rohani. Pertama; peperangan ini adalah peperangan melawan dosa. Dosa berperang melawan kita dan sebaliknya kita harus belajar berperang melawan dosa. Kedua; peperangan ini adalah peperangan melawan dosa yang multidimensi (dosa pribadi, dosa sosial, dan dosa supranatural). Dan ketiga; peperangan itu adalah peperangan rohani melawan dosa. Di belakang kejahatan daging dan kebobrokan dunia berdiri oknum yang menjadi sumber utama segala dosa itu, yaitu Iblis. $^{22}$ 7) Penginjilan, baptisan Roh

\footnotetext{
${ }^{22}$ Ed Murpy, "Kita Sedang Berperang," in $A d u$ Kuasa Dengan Penghulu Kegelapan (Bandung:
}

Kudus bagi kalangan kaum Kharismatik menggerakkan dan memimpin kepada gerakan penginjilan. 8) Pengusiran setan atau pelayanan pelepasan, kaum Kharismatik secara spesifik pelayanan pengusiran setan dan pelayanan pelepasan adalah pelepasan dari roh jahat meskipun dalam pengertian umum dapat berkaitan dengan kelepasan dari roh jahat, penyakit, depresi dan sebagainya. 9) Pengharapan Akhir Zaman, keyakinan kaum Kharismatik adalah jemaat mula-mula tahu bahwa Yesus telah naik ke surga dan mereka menantikan kedatangan-Nya kembali dari surga bagi umat-Nya. 10) Kecintaan pada Alkitab, sekalipun kalangan kaum Kharismatik menekankan karunia-karunia Roh Kudus tidak merosotkan nilai dan kewibawaan Alkitab sebagai otoritas, karena kehausan dan kecintaan terhadap Alkitab. ${ }^{23}$ Baptisan roh adalah doktrin utama yang dianut oleh gerakan Kharismatik yang disusul dengan suatu karya Roh Kudus yang disebut juga Karunia Roh.

\section{Gerakan Pentakostalisme Gelombang} Ketiga: Tanda-tanda dan Mujizat-Mujizat

Kelompok tanda-tanda dan mujizatmujizat ini menyebut dirinya sebagai

Kalam Hidup, 1990), 49-51.

${ }^{23}$ Daniel Sutoyo, Gerakan Pentakostalisme:

Sejarah Kebangunan Rohani Yang Mewarnai

Dunia Dan Injil Bagi Bangsa-Bangsa (Sukoharjo:

Born Win's Publishing, 2011), 303-306. 
Gerakan Pentakostalisme Gelombang Ketiga (The Third Wave Movement). ${ }^{242526}$ Sebelum gerakan ini muncul telah didahului dengan gerakan Pentakostalisme Klasik (kuno) yang sering disebut sebagai The First Wave Movement dan gerakan Kharismatik sebagai The Second Wave Movement. Gerakan Pentaksotalisme Gelombang Ketiga (tanda dan mujizat) tidak mau menyebut dirinya sebagai anggota gerakan Pentakostalisme Klasik maupun gerakan Kharismatik. Sekalipun begitu, ajaran Gerakan Pentakostalisme Gelombang Ketiga tentang karunia-karunia rohani tidak jauh berbeda dengan ajaran gerakan-gerakan sebelumnya (Pentakostalisme Klasik dan Kharismatik), namun hanya saja dalam gerakan Pentakostalisme gelombang ketiga ini, bahasa roh kurang ditekankan dan bukan keharusan serta dipandang sebagai karunia yang dimiliki untuk efektivitas pelayanan dan bahasa doa.

Gerakan

Pentakostalisme

Gelombang Ketiga ini banyak menjangkau kaum intelektual dan para akademisi di kalangan Injili. Tokoh-tokoh Kharismatik dari kalangan intelektual dan akademisi

\footnotetext{
${ }^{24}$ S Gary Greig and Kevin N. Spinger, eds., Kebutuhan Gereja Saat Ini (Malang: Gandum Mas, 2012), 27-29.

${ }^{25}$ Djaka Christianto Silalahi, Kharismatik Bercampur Dengan Perdukunan? (Yogyakarta: Andi Offset, 2001), 25-37.

${ }^{26}$ William W. Menzies and Robert P., Roh Kudus

Dan Kuasa (Malang: Gandum Mas, 2005), 45-47.
}

yang telah tergabung dalam gerakan Pentakostalisme gelombang ketiga ini, antara lain: C. Peter Wagner, pakar pertumbuhan Gereja, professor Sosiolog dan Antropologi dari Fuller Theological Seminary, Pasadena, California, AS; Jeck Deere, profesor Perjanjian Lama pada Dallas Theological Seminary, tetapi dikeluarkan dari institusi itu karena mengalami pengalaman supranatural baptisan Roh Kudus; Wayne Grudem, profesor Teologi Sistematika dan Alkitab di Trinity Evangelicl Divinity School, Deerfield Illinois, AS; Peter H. Davis, professor Studi Alkitab dan Perjanjian Baru di Canadian Teological Seminary, Regina, Kanada; Charles H. Kraft, professor Antropologi dan Komunikasi Antar Budaya di Fuller Tehological Seminary, Pasadena, California. AS; Jeffrey Niehaus, professor dan Ahli Perjanjian Lama, lulusan Liverpool dan pengajar di Gordon-Conwell Theological Seminary, di South Hamilton, AS, doktor (Ph.D) dalam bidang sastra Inggris dan Amerika; David C. Lewis, seorang Antropolog Budaya, seorang peneliti dari Cambrige University, Inggris; Gary S. Greig, seorang Arkeolog dan Ilmu Mesir Kuno, pakar dalam bidang Bahasa dan Peradaban Timur Tengah. ${ }^{27}$ Dengan kehadiran orang-orang akademis ini,

${ }^{27}$ Ibid, 11-15. 
masihkah kita menganggap bahwa gerakan-gerakan Pentakostalisme itu anti rasional dan intelektualitas?

Kelompok gerakan Pentakostalisme gelombang ketiga pada umumnya menerima pengalaman Pentakosta seperti gerakan gelombang pertama, Pentakostalisme klasik dan gerakan Pentakostalisme gelombang kedua, Kharismatik, tetapi menolak terminologi Pentakostalisme. Mengenai baptisan Roh Kudus dipandang tidak dapat dipisahkan dari pengalaman pertobatan (kelahiran baru), tetapi seorang dapat mengalami berkali-kali dipenuhi Roh Kudus. Pengurapan dan kuasa Roh Kudus lebih penting dibandingkan dengan pengalaman. Konteks pelayanan gerakan Pentakostalisme gelombang ketiga ini adalah kebersamaan dalam tubuh Kristus. Kelompok gerakan Pentakostalisme gelombang ketiga mendorong gereja dan kelompoknya agar mendapatkan "tanda dan mukjizat" (signs and wonders) sebagai perwujudan pekerjaan Roh Kudus diakhir zaman ini.

\section{Gerakan Gelombang Keempat: Gerakan}

\section{Gelombang Rasuli Baru}

Peter C. Wagner menyatakan bahwa telah melihat gelombang ketiga pada tahun 1980an membuka kaum evangelikal terhadap karya supranatural dari Roh Kudus yang sama yang dialami kaum gerakan Pentakostalisme Klasik dan gerakan Kharismatik, namun mereka tanpa menjadi kharismatik atau Pantekostal. Wagner menyatakan tentang gerakan Pentakostalisme gelombang keempat; "Saya pikir kita berada dalam gelombang baru dari sesuatu yang sekarang telah berlangsung hampir sepanjang abad kita."28 Pada musim semi tahun 2011, Wagner diberi mimpi kenabian yang jelas di mana John Wimber adalah tokoh sentral. Pemimpin Gelombang Ketiga yang hebat ini meskipun telah lulus dengan pahala surgawi pada tahun 1997. Pendeta musikal ini adalah salah satu negarawan terbesar yang bergerak dalam kekuatan otentik dalam sejarah gereja. Dalam mimpi yang menakjubkan ini, Roh Kudus menggunakan John Wimber sebagai suara representasional dari Gerakan Pentakostalisme Gelombang Ketiga. Wagner diberi tahu bahwa tujuan gerakan itu sekarang telah mereda dan tiba saatnya gelombang lain bergulir di gereja-gereja secara global, oleh beberapa orang menganggap sebagai New Apostolic Reformation (NAR) atau Gerakan Reformasi Apostolik Baru dengan berbagai

\footnotetext{
${ }^{28}$ Peter C. Wagner, "The Third Wave?," Pastoral Renewal, 1983, 1-5.
} 
jaringan dan ungkapan global yang beragam. $^{29}$

Jadi setelah Gerakan

Pentakostalisme Gelombang Ketiga (signs and wonders) muncul New Apostolic Reformation Movement atau Gerakan Reformasi Apostolik Baru (th.1999 atau 2011?). ${ }^{303132}$ Menurut Peter C. Wagner, Gerakan Reformasi Apostolik Baru adalah karya Tuhan yang luar biasa pada penghujung abad ke 20, yang secara signifikan sedang mengubah wajah Kristen Protestanisme di seluruh dunia. Selama hampir 500 tahun, gereja-gereja Kristen sebagian besar berfungsi dalam berbagai jenis struktur denominasi tradisional, secara khusus dasawarsa 1990-an, meski akarnya dapat ditelusuri kembali satu abad sebelumnya, bentuk-bentuk dan prosedurprosedur kerja yang baru kini sedang muncul dalam bidang-bidang semacam pemerintahan gereja lokal, hubungan antar gereja, pengaturan keuangan, penginjilan, misi, doa, pemilihan pemimpin dan pelatihan kepemimpinan, peran dari kuasa adikodrati, penyembahan, aspek-aspek penting lainnya dalam kehidupan gereja.

\footnotetext{
${ }^{29}$ Ibid.

${ }^{30}$ C. Peter Wagner, Gereja-Gereja Rasuli Yang Baru (Jakarta: Immanuel, 1999), 13-27.

${ }^{31}$ Robert Stearns, Chuck Pierce, and Larry Kreider, Today's Church (Yogyakarta: Andi Offset, 2013), 93-111.

${ }^{32}$ John Kingsley Alley, Pewahyuan Rasuli: Reformasi Dalam Gereja (Jakarta: Metanonia, 2007), 46.
}

Beberapa dari perubahan-perubahan ini sedang terlihat dalam diri denominasidenominasi mereka sendiri, namun sebagian besar mereka mengambil jejaring rasuli yang disusun dengan longgar. Hampir semua bagian dunia, gereja-gereja rasuli baru ini menyusun segmen kekristenan yang paling cepat pertumbuhannya yang oleh Stanley $M$. Burges disebut sebagai Pentakosta Kontemporer. $^{33}$

\section{Gerakan}

Pentakostalisme

Gelombang Keempat ini yang ditandai dengan suatu transformasi dalam segala kehidupan masyarakat. Baru-baru ini, Wagner berbagi dengan gereja-gereja bagaimana pada bulan Juli 2012, ia diberi sebuah penglihatan yang menunjukkan California sebagai rahim bagi Tubuh Kristus dalam perjumpaannya yang disebut Come Again Holy Spirit. Sebab sebelumnya ketiga Gelombang Pentakostalisme berasal dari atau memiliki pengaruh besar di California. Begitu juga dengan Gerakan Pentakostalisme Gelombang Keempat yang baru ini akan memiliki, dampak yang besar di California yang bersifat global.

Gerakan Pentakostalisme Gelombang Keempat ini menekankan

\footnotetext{
${ }^{33}$ Stanley M. Burges, "Pemberitaan Injil Dengan Karunia-Karunia Mukjizat Dalam Gereja MulaMula Setelah Zaman Alkitab," in Kebutuhan Gereja Saat Ini, ed. S Gary Greig and Kevin N. Spinger (Malang: Gandum Mas, 2012),341.
} 
perubahan masyarakat dengan memberdayakan orang-orang percaya untuk mempengaruhi 7 (tujuh) bidang kehidupan manusia sehari-hari, antara lain; Pegunungan Budaya Agama, Pemerintahan, Pendidikan, Bisnis, Keluarga, Media dan Seni, dan Entertainment. ${ }^{34}$ Strategi syafaat sekarang akan muncul untuk pelayanan yang efektif di tempat-tempat umum. Karena kekuatan supranatural berwujud karunia-karunia Roh Kudus tidak akan dapat hanya ditampung di dalam "empat dinding gereja," melainkan menerobos ke dalam setiap bidang kehidupan di tengah-tengah masyarakat.

Kaum Gerakan Pentakostalisme Gelompang Keempat mengklaim bahwa wahyu dapat diterima langsung dari Tuhan. Beberapa dari mereka menyatakan bahwa mereka telah sering mengunjungi surga dan melakukan percakapan dengan Yesus sama dengan para nabi dan rasul. Jangkauan misi New Apostolic Reformation (NAR) yang ekstensif di seluruh dunia telah menyebabkan pertumbuhan gereja yang menakjubkan yang terjadi di Afrika, Asia, dan Amerika Latin.

Berikut adalah 6 ciri, kepercayaan, dan beberapa istilah umum yang digunakan

\footnotetext{
${ }^{34}$ Mikhael Maiden, The Seven Mountains: Memuridkan Bangsa-Bangsa Dengan Strategi Tujuh Gunung (Yogyakarta: Andi Offset, 2012).
}

oleh penganut New Apostolic Reformation (NAR): Pertama, Para Rasul. Menurut mereka bahwa sekarang berada dalam "Zaman Apostolik Kedua." Di bumi saat ini ada beberapa rasul baru, yang diurapi oleh peletakan tangan untuk mewakili dan berbicara atas nama Tuhan di bumi. Dalam kelompok ini ada istilah Super Apostles yang berarti bahwa ada rasul yang sama dengan para rasul yang mula-mula, yaitu orang-orang yang menyaksikan kehidupan Yesus, kematian dan kebangkitan dan ditunjuk oleh Kristus sendiri ke dalam pelayanan. Karena para rasul baru ini ditugaskan oleh Tuhan dengan otoritasNya.

Kedua, Kerajaan. Alih-alih mengkhotbahkan Injil salib, para pemimpin Apostolik bekerja untuk membawa Injil Kerajaan Surga ke bumi. Mereka melakukan ini dengan mengambil alih kerajaan duniawi atau "pegunungan" yaitu Pegunungan Budaya Agama, Pemerintahan, Pendidikan, Bisnis, Keluarga, Media dan Seni, dan Entertainment. Pemimpin sering berbicara tentang pembangunan kota dan mengatur doa peperangan untuk berdoa melawan benteng-benteng setan. Sehingga mereka dituduh sering banyak berbicara tentang fokus misi daripada berpusat pada Kristus.

Ketiga, Destiny, Kehadiran Tuhan dan Kemuliaan. Meskipun anggota New 
Apostolic Reformation (NAR) tidak selalu pentakosta dan karismatik, namun mereka sering menekankan manifestasi "Kemuliaan" dan "kehadiran Tuhan," dan seringkali memiliki pengurapan khusus untuk menerima wahyu langsung dari Tuhan, melakukan penyembuhan dan tanda-tanda dan mujizat-mujizat lainnya. Mereka mengajarkan bahwa tujuan kita adalah mencapai takdir impian kita sehingga kita bisa mengubah dunia.

Keempat, Kebangunan Rohani. Kebangunan-kebangunan rohani pada skala besar adalah kunci dalam gerakan Pentakostalisme gelombang keempat ini. Ada penekanan yang kuat yaitu "akhir zaman penuaian" melalui kebangunankebangunan rohani besar, yang seringkali kebangunan rohani ini diadakan di stadionstadion dan menjangkau jutaan orang di seluruh dunia melalui teknologi live streaming yang dikemas dengan konserkonser musik.

Kelima, Kesatuan, kesatuan ini (bahkan dengan mengorbankan doktrin alkitabiah) hampir selalu digunakan dalam usaha untuk menyatakan baik bagaimana dan mengapa ada gerakan ini. Persatuan demi membawa Surga ke bumi mengarah pada kekaburan garis-garis doktrinal dan denominasi, yang sering menyatukan para pemimpin gereja kharismatik, reformasi, mainstream, gereja pentakostalisme bahkan Gereja Katolik Roma yang terkenal, semua di bawah satu payung, yaitu New Apostolic Reformsation.

Keenam, Menyangkal Kecukupan Alkitab. Gereja-gereja New Apostolic Reformation hampir selalu meninggalkan keyakinan iman Kristen yang utama. Pengikut New Apostolic Reformsation mungkin percaya pada ketidakmampuan dan otoritas Alkitab, namun Firman Allah yang bernafas tidak cukup bagi mereka. Kematian pengorbanan Yesus karena dosadosa kita tidak cukup baik; janji hidup kekal di surga tidak cukup baik.

Pendiri New Apostolic Reformation adalah spesialis pertumbuhan gereja Peter C.Wagner. Wagner menjabat sebagai Profesor Pertumbuhan Gereja di Sekolah Misi Fuller Theological Seminari sampai masa pensiunnya. Sampai saat ini dia adalah presiden dari Global Harvest Ministries dan saat ini menjabat sebagai Kanselir emeritus dari Wagner Leadership Institute. Anggota terkemuka adalah Chuck Pierce adalah penggantinya dari Dewan Apostolik Internasional.

Tokoh-tokoh lain dari New Apostolic Reformation adalah Bob Jones; Cindy Jacobs; Mike Bickle (International House of Prayer-IHOP); Rick Joyner; Bill Johnson (Bethel Church, Redding CA); Todd Bentley; Lou Engle; Brian \& Bobbie Houston (Hillsong Church); Becky 
Fischer; Brian Simmons; Steve Shultz (The Elijah List); Michael Brown; Rod Parsley, nama-nama yang lain; John Kelly, Bill Haman, Dutch Sheets, James Goll, John Eckhardt, Jim Laffoon, Jack Deere, Johnny Enlow, Barbara Yoder, Charles Kraft, Bob Beckett, Che Ahn, Naomi Dowdy, Mary Crum, Jack Hayford, John Arnott, Stacy Campbell, Patricia King, Phil Pringle, Yonggi Cho, Beni Johnson, Jen Johnson, Kris Vallotton, Carl Lentz, David Barton, Steven Strang, Robert Stern, Stephen Strader, George Otis, Ed Silvoso, Janet Porter, George Barna, Mary Glazier, Thomas Muthee, Tom Hess, Samuel Rodriguez, Eddie Smith, Lance Wallnau, Loren Cunningham, Bob Beckett, Os Hillman, Jacqueline del Rosario, Jill Griffith, Francis Oda, Graham Power, Francis Frangipagne, Wendy Alec, Amanda Wells, Katherine Ruonala, Lana Vawser, Kong Hee \& Sun Ho, Theo Wolmarans, Jennifer LeClaire dan masih banyak lagi.

\section{METODE PENELITIAN}

Metode dalam penelitian ini adalah penelitian analisis historis terhadap sejarah perkembangan setiap gerakan gelombang Pentakostalisme. Melalui penelitian yang jujur dan seksama terhadap catatan sejarah gereja, akan memperlihatkan dan menjelaskan kepada kita bahwa ajaran dan praktek karunia-karunia rohani terus berlangsung selama berabad-abad, sejak zaman para rasul hingga saat ini. Tujuan penelitian historikal adalah untuk membuat rekonstruksi masa lampau secara sistematis dan objektif, dengan cara mengumpulkan, mengevaluasi, memverifikasi serta mensintesiskan bukti-bukti untuk menegakkan fakta dan memperoleh kesimpulan yang kuat. ${ }^{35}$

Analisis historis tidak dapat dilepaskan dengan tafsiran sejarah yang merupakan gambaran yang dihasilkan oleh perasaan atau pikiran manusia. Tafsiran sejarah berisi pendapat dan pandangan teoritis terhadap dokumen sejarah dengan mengadakan analisis serta sintesis. Salah satu hal penting di dalam tafsir sejarah, adalah subjektifitas dan objektivitas dalam sejarah.

Para sejarawan dituntut untuk objektif dalam usaha menyusun sejarah. Objektivitas ini didasarkan atas tanggung jawab pada kebenaran objek sejarah. Fakta-fakta atau peninggalan masa lalu disebut objek sejarah, yang berwujud dokumen tertulis. Fakta atau peninggalan masa lalu dalam wujud dokumen sejarah, akan memiliki arti sejarah apabila sudah mendapat interpretasi atau tafsiran yang dapat dipercaya mengenai bahan-bahan

\footnotetext{
${ }^{35}$ Marzuki, Metodologi Riset: Panduan Penelitian Bidang Bisnis Dan Sosial (Yogyakarta: Ekonisia, 2005), 26
} 
yang otentik. Karena itu, tugas peneliti atau ahli sejarah adalah mencari sumbersumber informasi, mengevaluasi kebenarannya, melakukan penyelidikan, berdisiplin akan artinya dan dengan imajinasi merekontruksi apa yang terjadi.

Tafsiran sejarah merupakan gambaran yang dihasilkan oleh perasaan atau pikiran manusia. Tafsiran sejarah ini disebut subjektivitas. Seorang sejarawan harus berusaha untuk seobjektif mungkin dalam menyusun sejarah. Tetapi, bagaimana pun juga subjektivitas dalam penulisan sejarah tidak bisa dihindari. Bagaimanapun juga objektivitas diusahakan, subjektivitas itu pasti akan ada, dan seorang sejarawan dapat tenggelam dalam subjektivitas. Sebab untuk dijadikan sejarah, objek sejarah haruslah ditafsirkan oleh subjek sejarah. Karena itu, kepada para sejarawan selalu dituntut, supaya ia dengan sadar dan jujur mengikatkan diri pada objek dan berpikir secara objektif. Ini artinya subjektivitasnya harus diusahakan seobjektif mungkin, ia harus menghindari subjektivisme atau kesewenang-wenangan subjek.

\section{ANALISIS DAN HASIL}

Bagaimana sikap kita untuk meresponi terhadap ajaran, perilaku dan fenomena-fenomena dari gerakan
Pentakostalisme melalui gelombanggelombang? Kita sebagai orang akademisi dalam bidang teologi (kaum Pentakostalisme) dengan berani menentukan sikap yang tegas terhadap setiap bentuk ajaran setiap gerakan Pentakostalisme demi kebenaran iman Kristen. Sebagai seorang akademisi teologi perlu untuk menguji dengan teliti tanpa suatu prasangka sebelum terbukti. Rasul Yohanes mengingatkan, "Saudarasaudaraku yang kekasih, janganlah percaya akan setiap roh, tetapi ujilah roh-roh itu, apakah mereka berasal dari Allah; sebab banyak nabi-nabi palsu yang telah muncul dan pergi ke seluruh dunia" (1Yoh. 4:1). Frase Yunani "ujilah roh-roh itu" dalam 1 Yohanes 4:1 terjemahan dari dokimazete ta pneumata. Kata dokimazetre berasal dari kata dokimazo dalam Perjanjian Baru muncul 22 kali yang berarti "menguji, membuktikan dengan menguji,mengetahui, menyetujui, menganggap perlu, menganggap tahan uji." Alasan untuk menguji setiap roh atau menguji gerakan yang menyatakan gerakan Roh Kudus untuk memastikan bahwa gerakan tersebut benar-benar karya Roh Kudus. Sebab saat ini ada banyak nabinabi palsu yang menyusup dan masuk ke dalam gereja, khususnya geraja beraliran Pentakosta-Kharismatik (Mrk.13:22).

\footnotetext{
${ }^{36}$ Hasan Susanto, Perjanjian Baru Interlinear Yunani-Indonesia Dan Konkordansi Perjanjian Baru (Malang: SAAT, 2004), 220.
} 
Batu uji yang digunakan untuk menguji ajaran dan perilaku setiap gerakan Pentakostalisme adalah ajaran dan perilaku yang masih diragukan. Dalam melakukan pengujian ini ada beberapa pertanyaan yang harus mendapatkan jawaban yang pasti. Pertanyaan-pertanyaan itu, antara lain; 1) Apakah ajaran atau perilaku setiap gerakan Pentakostalisme sesuai dengan ajaran Alkitab sebagai firman Tuhan yang tidak salah? 2) Apakah ajaran atau perilaku setiap gerakan Pentakostalisme tersebut memuliakan Tuhan Yesus? 3) Apakah ajaran atau perilaku dari setiap gelombang gerakan Pentakostalisme tersebut mendatangkan pertobatan dan damai sejahtera dalam kelompoknya? Maksud kita melakukan pengujian adalah akan terhindar dari kesesatan rohani yang dapat berakibat fatal dan mengalamai kematian kekal. Tuhan Yesus mengingatkan, "dari buahnyalah kamu akan mengenal mereka" (Mat. 7:17). Yang dimaksud dengan buah di sini bukanlah hasil pekerjaan berupa kemampuan untuk "bernubuat, mengusir setan dan penyembuhan," melainkan kemurnian ajaran teologi, motivasi praktek, dan karakter hidupnya yang sesuai dengan kehendak Tuhan (Mat. 7:21). Pada bagian ini tidak dimaksudkan untuk menyatakan semua "nubuat, mujizat, kesembuhan" itu palsu, melainkan peringatan kepada orang Kristen untuk mewaspadai "kepalsuan".

\section{Dasar Teologis}

\section{Roh Kudus akan Terus Dicurahkan}

Keyakinan kaum gerakan Pentakostalisme adalah Roh Kudus akan terus-menerus dicurahkan kepada gerejaNya. Bahkan pencurahan yang lebih besar akan terjadi pada waktu yang akan datang. Karena gereja-Nya pada akhir zaman akan lebih banyak membutuhkan kuasa Roh Kudus untuk melengkapi gereja-Nya untuk melaksanakan tugas-tugas menjelang kedatangan-Nya. Kuasa dan manifestasi Roh Kudus pada akhir zaman akan dicurahkan seperti hujan awal dan hujan akhir, Roh Kudus akan memperlengkapi gereja-Nya untuk menuai jiwa-jiwa. Maka gereja-Nya harus siap sedia untuk menerima Roh Kudus untuk melakukan penuaian besar-besar pada akhir zaman.

Pencurahan Roh Kudus sebagaimana dinubuatkan dalam khotbah Petrus (Kis. 2:17-18) telah melanda seluruh dunia sampai pada hari ini. Pengalaman Roh Kudus yang terjadi di Azusa Street di tahun 1906 sebenarnya bukan hal yang baru. Pencurahan Roh Kudus terjadi di revival di Wales Inggris, Pensacola, Toronto Kanada, Almolonga Guatemala, bahkan di Chili, gereja yang dipimpin oleh pendeta Willis C. Hoover, 
mengalami pertumbuhan pesat setelah mengalami pencurahan Roh Kudus seperti itu. Dari 365 anggota bertumbuh menjadi 650.000 anggota pada tahun 1986. Jemaat mengalami banyak mujizat dan menjalankan karunia-karunia Roh Kudus seperti pada zaman para rasul dan gereja pertama. $^{37}$ Di Chili sendiri, 90 persen orang Kristen beraliran PentakostaKarismatik telah mengalami pencurahan Roh Kudus.

\section{Kebangkitan gelombang-} gelombang dari gerakan Pentakostalisme ini menunjukkan kebangkitan kegairahan kuasa Roh Kudus yang membara yang terlihat dalam setiap Kebaktian Kebangunan Rohani yang diadakan secara besar-besaran. Sekalipun ada beberapa pihak yang menyatakan gelombanggelombang gerakan Pentakostalisme adalah sesat, tetapi pada dasarnya ini merupakan fenomena gerakan Pentakostalisme secara positif adalah Roh Kudus sedang bekerja di seluruh dunia untuk memulihkan gereja-Nya dengan mencurahkan Roh Kudus-Nya.

\section{Karunia-karunia Roh Kudus Masih}

\section{Berlanjut}

Dalam Perjanjian Baru untuk mendeskripsikan "karunia-karunia Roh"

\footnotetext{
${ }^{37}$ Haryadi Baskoro, 77 Renungan Alkitabiah Tentang Akhir Zaman (Yogyakarta: Andi Offset, 2011), 75 .
}

adalah charisma ${ }^{38}$ Kata charisma berasal dari kata charis yang berarti "anugerah; pemberian; kemurahan hati; senang; keramahan; syukur; pahala; faedah"39 Kata charisma kini memiliki makna yang beragam sesuai dengan konteks penggunaannya. Kata charisma muncul berkali-kali dalam tulisan Paulus dan memiliki keragaman arti yang luas. Kata ini dapat dipakai untuk berbagai pemberian Allah. Karunia untuk menikah atau selibat disebut charisma (1Kor. 7:7). Kata ini juga digunakan untuk karunia keselamatan ( $\mathrm{Rm}$. 5:15-16; 6:23), keselamatan secara fisik (2Kor. 1:11) maupun pilihan Allah atas Israel (Rm. 11:29). Melalui penggunaan istilah charisma Paulus ingin menunjukkan bahwa karunia-karunia dari Allah tidak dapat dibatasi pada daftar karunia rohani yang terlihat spektakuler di 1 Korintus 12:7-11. Masih banyak karunia rohani lain yang Allah berikan pada setiap orang Kristen secara berbeda. Jadi disini "charisma" dihubungkan dengan "penebusan atau keselamatan" dalam Kristus. Pada kesempatan yang lainnya, kata ini dihubungkan dengan "pertolongan" (2Kor. 1:11). Kata ini pada dasarnya berarti "karunia, anugerah, pemberian atau hadiah.” Lembaga Alkitab

\footnotetext{
${ }^{38}$ Anthony A Hoekema, Diselamatkan Oleh Anugerah (Surabaya: Momentum, 2010), 40. ${ }^{39}$ Susanto, Perjanjian Baru Interlinear YunaniIndonesia Dan Konkordansi Perjanjian Baru, 809.
} 
Indonesia juga menterjemahkan dengan istilah "kasih karunia" atau "anugerah". Kata charisma juga dari kata kerja charizomai yang berarti "memberi." Akhiran "ma" menyatakan sesuatu yang berwujud yaitu hasil atau akibat dari suatu perbuatan. Kata charisma merupakan suatu perwujudan dari charis (anugerah) dan hasil dari perbuatan charizomai (memberi). Kata charisma berarti yang menunjuk pada hasil atau akibat dari charis yang dipandang sebagai suatu tindakan tanpa dengan pengertian. Jadi bentuk jamak dari kata charisma adalah charismata. Dari kata inilah kemudian muncul sebutan kharismatika yang menunjuk kepada "gerakan Kharismatik" atau "orang-orang Kharismatik." $" 40$ Jadi karunia-karunia Roh Kudus adalah suatu karya Roh Kudus yang dianugerahkan kepada gereja-Nya, supaya gereja-Nya melaksanakan tugas-tugasnya. Karunia-karunia Roh Kudus bukan usaha manusia, melainkan pemberian Allah secara cuma-cuma untuk memperlengkapi gereja-Nya dalam melaksanakan misi di dunia.

Dalam Perjanjian Baru ada beberapa daftar karunia-karunia rohani atau charismata yang disebutkan, seperti di dalam Roma 1:11; 5:15, 16; 6:23; 11:29; 12:6; 1 Korintus $1: 7 ; 7: 7 ; 12: 4,9,28,30$,

\footnotetext{
${ }^{40}$ Peter C. Wagner, Manfaat Karunia-Karunia Rohani Untuk Pertumbuhan Gereja (Malang: Gandum Mas, 1998), 41.
}

31; 2 Korintus 1:11; 1 Timotius 1:6; 4:14; 1 Petrus 4:10, oleh para penganut Pentakostalisme diakui bukan hanya berlaku bagi gereja masa lalu tetapi juga untuk gereja masa kini. Karunia-karunia rohani harus menjadi bagian dari gereja hingga Kristus datang kembali. Bagi kelompok gerakan Pentakostalisme bahwa eksistensi dan kontinuitas dari karuniakaruni Roh Kudus merupakan sine qua non (syarat yang tidak boleh tidak ada) bagi gerakan Pentakostalisme.

Karunia-karunia Roh Kudus merupakan pemberian dari Allah sendiri yang di dasarkan pada anugerah-Nya yang digunakan untuk membangun gerejaNya. ${ }^{41}$ Artinya bahwa karunia-karunia Roh Kudus yang diberikan bukan dipakai untuk kepentingan pribadi diri sendiri, melainkan untuk membangun orang lain di dalam pertumbuhan iman dan kerohanian mereka di dalam persekutuan tubuh Kristus. Karunia-karunia Roh Kudus yang ada ini adalah semuanya berasal dari anugerah dan karya supranatural Allah yang satu (1Kor. 12:13) sehingga dapat dibedakan antara karunia yang diberikan oleh Allah dan apa yang merupakan bakat alamiah.

Jadi gelombang-gelombang dari gerakan Pentakostalisme adalah sebuah gerakan yang berasal dari Tuhan, yang

\footnotetext{
${ }^{41}$ Donald Bridge and David Phypers, Spiritual Gifts and The Church (Illinois: Inter-Varsity Press, 1973), 19.
} 
mana Tuhan memberikan karunia-karunia Roh Kudus yang didukung oleh pernyataan Alkitab. Jadi karunia-karunia Roh Kudus seperti; mujizat, kesembuhan, bahasa roh, nubuat, menafsir bahasa Roh, iman, dan lainnya masih terus eksis dan berlangsung hingga saat ini di dalam rangka untuk membangun gereja-Nya, yaitu tubuh Kristus. Gelombang-gelombang gerakan Pentakostalisme ini murni dari Allah, tetapi ada yang telah dicemari oleh fenomena-fenomena yang "kebablasan" dari ajaran-ajaran dan praktek-praktek yang bersifat tidak sehat, sensasional dan fenomenal.

\section{Gerakan Pentakostalisme Percaya Roh} Kudus adalah Allah.

Jika kelompok Protestanisme dan Evangelicalisme yakin bahwa Roh Kudus adalah Allah, demikian juga penganut gerakan Pentakostalisme percaya keilahian Roh Kudus. Keilahian Roh Kudus dapat dilihat dari sifat-sifat yang dimiliki-Nya yang hanya dimiliki oleh Allah sendiri seperti: Dia terlibat dalam penciptaan dunia (Kej. 1:2); Ia kekal (Ibr. 9:14); Ia Mahahadir (Mzm. 139:7-10); Ia Mahakuasa (Luk. 1:35). Dia mengilhami para penulis Kitab Suci (2Ptr. 1:21); Ia sanggup berada dimana-mana pada satu ketika, di saat yang sama; Ia Mahatahu (1Kor. 2:10, 11); Ia mengetahui segala sesuatu; Ia memiliki kuasa untuk melakukan segala sesuatu; Ia sederajat dengan Bapa dan Anak (Mat. 28:19).

\section{Keseimbangan Teologi dan Praktek}

Di atas telah dinyatakan bahwa karunia-karunia Roh Kudus, termasuk mujizat dan bahasa roh dan lainnya masih eksis hingga kini untuk membangun gereja-Nya, yaitu tubuh Kristus. Tetapi ada beberapa oknum (pribadi) dalam prakteknya "kebablasan" yang seringkali menyimpang dan mengajarkan yang lain dengan tafsiran yang tidak sehat dan tidak alkitabiah. Sebenarnya gerakan Pentakostalisme ini murni dari Allah, merupakan gelombang karya Roh Kudus, tetapi telah dicemari dengan praktekpraktek yang bersifat sensasionalfenomenal pribadi, sebagaimana gerakangerakan pembaharuan lainnya dalam sejarah gereja. Kelompok Pentakostalisme mengakui sesuai di lapangan ada praktekpraktek Pentakostalisme secara pribadi telah menyimpang dari tujuan dan maksud karunia-karunia Roh Kudus diberikan. Namun demikian, bukan berarti semua gelombang gerakan Pentakostalisme secara digeneralisasi adalah gerakan yang sesat dan bidat. Jika ada kaum gerakan Pentakostalisme secara subyektif mengajarkan dan melakukan praktek mujizat-mujizat palsu (mujizat tiruan yang 
berasal dari setan), bukan berarti kita harus secara frontal menolak semua mujizat yang terjadi, karena menganggapnya semua mujizat adalah palsu yang berasal dari setan. Sebaiknya perlu diuji dengan batu ujian ajaran Alkitab. Sebab setiap gelombang gerakan Pentakostalisme juga menekankan keseimbangan antara doktrinal dan praktikal, intektualisme dan spiritualisme, pengetahuan firman Tuhan dan pengalaman.

Semua orang Kristen harus menerima ajaran Kristen (doktrin) yang kemudian untuk dilakukan (dipraktekkan) ajaran Kristen itu dalam ketaatan, sukacita, kekudusan, dan kasih kepada Kristus. Dalam hal ini Yesus mengatakan kepada para murid-Nya supaya mengajarkan dan melakukan segala sesuatu yang telah diperintahkan-Nya kepada mereka (Mat. 20:20). Jadi doktrin (ajaran Kristen) tanpa dipraktekan dalam hidupnya, dapat diilustrasikan seperti manusia terdiri dari tengkorak yang tanpa daging; keras dan tak berbelas kasihan. Praktek tanpa dituntun doktrin sama seperti manusia yang hanya memiliki daging tanpa tulang; tidak memiliki kekuatan, lemah dan tak berdaya.

Demikian juga rasul Paulus menasihati kepada Titus; "Tetapi engkau, beritakanlah apa yang sesuai dengan ajaran yang sehat" (Tit. 2:1). Selanjutnya rasul Paulus menghubungkannya ajaran sehat dengan praktek kehidupan sehari-hari (Tit. 2:1-14). Ajaran sehat adalah doktrin (didache) yang selalu berkaitan dengan apa yang diajarkan. Ajaran sehat akan memelihara orang percaya agar tetap sehat dan terhindar dari kekeliruan. Doktrin yang sehat menghasilkan pertumbuhan dan paktek kehidupan kudus dan berkenan kepada Allah.

Rasul Paulus pernah mengatakan kepada jemaat di Roma; "Sebab aku ingin melihat kamu untuk memberikan karunia (charisma) rohani kepadamu guna menguatkan kamu" (Rm. 1:11). Artinya karunia-karunia Roh Kudus yang disediakan dan diberikan oleh Tuhan harus dipraktekkan guna membangun anggota tubuh Kristus, yaitu gereja-Nya. Karunia Roh diberikan dan digunakan untuk tujuan pelayanan. ${ }^{42}$ Roh Kudus yang memberikan karunia-karunia-Nya kepada setiap orang percaya menurut kehendak-Nya. Rick Cornish menyatakan, "Setiap orang percaya memiliki paling sedikit sebuah karunia, karena Roh Kudus "yang memberikan karunia kepada tiap-tiap orang secara khusus" (1Kor. 12:11)." Alkitab mengajarkan bahwa setiap orang

\footnotetext{
${ }^{42}$ Desti Samarenna, "Analisis 1 Korintus 14:2-6 Tentang Karunia Berbahasa Roh Dan Bernubuat," DUNAMIS: Jurnal Penelitian Teologi dan Pendidikan Kristiani 2, no. 1 (November 4, 2017): 1, accessed April 20, 2018, http://sttintheos.ac.id/ejournal/index.php/dunamis/article/view/128.

${ }^{43}$ Rick Cornish, Lima Menit Teologi (Bandung: Pionir Jaya, 2007), 278.
} 
percaya menerima minimal satu karunia, maka karunia tersebut harus terus-menerus diaktifkan dalam kehidupan, supaya orangorang percaya yang menerimanya mengalami pertumbuhan iman yang signifikan. Jika seorang percaya tidak mengaktifkan karunia yang Tuhan berikan kepadanya, maka karunia tersebut tidak akan berguna dan manfaat untuk membangun tubuh Kristus. Karunia Roh Kudus yang diberikan Tuhan kepada orang percaya untuk kepentingan bersama" (1Kor. 12:7). Cornish menyatakan, "Jikalau kita mengabaikan karunia-karunia kita, kita telah kehilangan potensi pemberian Allah. Kita juga merampok gereja dengan apa yang Allah percayakan kepada kita. Karena pertumbuhan rohani pribadi terkait dengan pertumbuhan seluruh tubuh (Kristus), kita juga mencurangi diri sendiri. Ketika kita menggunakan karunia-karunia yang Allah percayakan kepada kita, tim-Nya akan berjaya dan Ia dimuliakan."44 Demikian juga A.W Tozer mengatakan, "Diberkatilah orang yang mengenal karunia-karunianya dan yang ingin mempraktekkannya untuk anggota lain dalam tubuh Kristus "sebagai pengurus

\footnotetext{
${ }^{44}$ Ibid, 280-281.
}

yang baik dari kasih karunia Allah" (1Ptr. 4:10)."45

Pneumatologis Sebagai Prinsip Pemersatu Setiap Gelombang Gerakan Pentakostalisme.

Prinsip pemersatu setiap gelombang gerakan Pentakostalisme adalah pneumatologis, artinya gelombanggelombang gerakan Pentakostalisme dalam pengajaran dan prakteknya yang berorientasi pada kuasa dan karuniakarunia Roh Kudus. Penganut setiap gelombang gerakan Pentakostalisme adalah orang-orang atau kelompokkelompok yang hidup pada zaman yang berbeda, bahkan ada yang tidak saling mengenal satu dengan lainnya. Dan sampai saat ini, setiap gelombang gerakan Pentakostalisme ini ada di dalamnya orang-orang dari berbagai suku, bangsa, bahasa, latar belakang, bahkan berbagai denominasi gereja. Latar belakang yang beragam ini menyebabkan ketidaksepahaman doktrinal dalam hal-hal tertentu, misalnya: tentang keselamatan, dosa, gereja, baptisan air dan sebagainya, sekalipun mereka berbeda-beda doktrin dan ajaran, namun mereka mempunyai semangat persatuan, yaitu prinsip pneumatologis. Sekalipun ada perbedaan antara satu dengan yang lainnya dari

\footnotetext{
${ }^{45}$ A.W. Tozer, Tentang Roh Kudus (Batam: Gospel Press, 2002), 251.
} 
kelompok-kelopok setiap gelombang gerakan Pentakostalisme ini. Tetapi uniknya, dalam keragaman ini para penganut gerakan Pentakostalisme ini bisa bersatu dalam kuasa, karya-karya dan karunia-karunia Roh Kudus masa kini. Itu sebabnya, tidaklah berlebihan jika dapat disimpulkan bahwa prinsip pemersatu dalam gerakan Pentakostalsime ini bersifat pnematologis.

\section{Evaluasi Kritis Gerakan Gelombang Pentakostalisme}

Setiap gelombang gerakan Pentakostalisme mempunyai ajaran dan prakteknya yang berbeda-beda, namun ada beberapa penganut atau kelompok dari gerakan itu mengklaim dirinya sebagai kaum gerakan Pentakostalisme yang "kebablasan" dalam ajaran dan perilakunya. Orang-orang atau kelompok tersebut secara subyektif mengklaim pengalaman fenomenal tertentu sebagai berasal dari Roh Kudus. Misalnya, ada seorang yang mengeksploitasi pengalaman-pengalaman spiritual seperti pengalaman dibawa oleh Tuhan untuk melihat surga atau neraka, diangkat ke surga dan kembali ke dunia, menari dalam roh, tertawa dalam roh, menggonggong dalam roh, meraung dalam roh bahkan muntah-muntah dalam roh dan menikah dalam roh. Stanley M. Burgess menyatakan bahwa dalam abad ke-20, ada beberapa orang pengajar gerakan Pentakostalisme tanpa disadari sudah menambah kebingungan dengan mengajarkan bahwa Roh Kudus. ${ }^{46}$ Bagi kelompok setiap gelombang gerakan Pentakostalisme dengan terbuka untuk menerima kritik dari berbagai pihak sebagai bukti kedewasaan dalam spiritual.

\section{Dampak Sisi Positif}

Memang perlu diakui bahwa setiap gelombang gerakan Pentakostalisme membawa dampak positif bagi kekristenan secara pribadi maupun secara kelompok. Salah satu hal yang paling menonjol pengaruhnya adalah membawa orangorang untuk lebih antusias mengenai halhal spiritual, khususnya hubungannya dengan Tuhan. Secara rohani mereka lebih berkobar-kobar bagi Tuhan, baik dalam hal melayani, memberitakan Injil, mensharingkan pengalaman mereka, dengan berani bersaksi, menceriterakan berkat-berkat Tuhan yang mereka terima, mengajak orang lain ke gereja, maupun dalam memberi persembahan (kemungkinan dan sekalipun dalam hal ini motivasinya seringkali salah). Roh Kudus tersebut berperan mengobarkan semangat

\footnotetext{
${ }^{46}$ Greig and Spinger, "Kebutuhan Gereja Saat Ini."
} 
pelayanan yang efektif dan berdampak besar. $^{47}$

Kelompok gerakan Pentakostalisme dapat lebih bebas dan luwes memuji Tuhan secara impresif maupun ekspresif baik itu di tempat umum dan tempat pribadi masing-masing. Mereka sangat menikmati waktu-waktu untuk bernyanyi dan menyembah Tuhan. Dalam hal ini mereka jauh lebih baik dan lebih bersemangat memuji dan menyembah Tuhan. Sekalipun ini adalah segi positif mereka, seringkali di sini juga terletak kelemahan mereka karena: Puji-pujian yang terlalu lama itu (kadang-kadang mencapai satu setengah jam atau lebih) yang mengurangi waktu pemberitaan Firman Tuhan. Pada waktu firman Tuhan diberitakan jemaat sudah lelah dan loyo, sehingga pada saat mendengar khotbah menjadi kesulitan untuk berkonsentrasi terhadap mendengar firman Tuhan.

Kelompok gerakan Pentakostalisme dengan berani atau tidak malu menyaksikan kebaikan Tuhan kepada sesama mereka, baik itu sesama orang Kristen atau juga dengan orang nonKristen. Pemberitaan Injil menjadi mudah dan efektif untuk diterima oleh para

\footnotetext{
${ }^{47}$ Yushak Soesilo, "Pengalaman Pribadi Dengan Roh Kudus Sebagai Indikator Kualitas Pelayanan," Jurnal Antusias 1, no. 3 (September 1, 2011): 109117, accessed March 4, 2018, http://sttintheos.ac.id/ejournal/index.php/antusias/article/view/79/78.
}

pendengarnya oleh karena adanya karya Roh Kudus. ${ }^{48}$ Dibandingkan dengan kebanyakan gereja Protestanisme, apalagi khususnya golongan Liberal (yang mempercayai bahwa di luar Kristus ada jalan keselamatan), kelompok gerakan Pentakostalisme lebih berani memberitakan Injil dengan memberikan kesaksian bahwa Yesus sebagai Juruselamat dan Tuhan, Pembuat mujijat, Penyembuh dan sumber berkat.

Kelompok gerakan Pentakostalisme memberi pengaruh dalam hal spiritualitas, artinya mereka menjadi semakin terbuka terhadap pengalaman diri mereka untuk berbagi kepada sesama mereka agar orang lain juga dapat merasakan pengalaman dengan Roh Kudus. Mereka lebih berhasil menarik orang-orang beragama lain untuk masuk ke gereja. Selain itu, Alkitab dan doa adalah hal penting dalam kehidupan mereka. Mereka gemar bersekutu dan mempelajari Alkitab. Ketika mereka mulai mempelajari Alkitab, mereka juga mulai mengambil hal-hal baik dari Alkitab dan kembali berkomitmen untuk hidup rohani mereka yang lebih baik. Roh Kudus menolong pola pikir dan penalaran manusia yang terbatas dalam memahami Alkitab sehingga diperoleh pemahaman

\footnotetext{
${ }^{48}$ Daniel Sutoyo, "Peran Roh Kudus Dalam Pemberitaan Injil," Jurnal Antusias 1, no. 3 (September 1, 2011): 17-26, accessed February 25, 2018, http://sttintheos.ac.id/ejournal/index.php/antusias/article/view/71/70.
} 
yang benar dan bertanggung jawab terhadap teks-teks Alkitab. ${ }^{49}$

Kelompok gerakan Pentakostalisme melibatkan emosi (perjumpaan, encounter) dalam pertemuan-pertemuan ibadah. Kelompok ini dalam ibadah bukan hanya dengan otak, tetapi juga dengan perasaan atau emosi kita (bdk. Mat. 22:37). Dalam ibadah tidak sedikit anggota jemaat yang menangis, terisak-isak, menangis dengan histeris karena emosinya dijamah oleh Roh Kudus, sehingga mereka merasa dibebaskan oleh Roh Kudus.

\section{Dampak Negatif}

Hampir seluruh gereja di dunia telah terpengaruh pengajaran dan praktek gerakan Pentakostalisme ini. Semua gereja dan denominasi telah banyak pula membicarakan mengenai bahasa Roh, mujizat-mujizat baik itu melalui diskusi, penerimaan, dan penolakan. Selain dampak positif gerakan Pentakostalisme mempunyai beberapa kelemahan dan kekurangan dari gerakan ini.

Ada beberapa tokoh dari gerakan Pentakostalisme ini menekankan pada teologi sukses dan teologi kemakmuran, dimana mereka sering menekankan bahwa orang Kristen haruslah kaya, karena itu

\footnotetext{
${ }^{49}$ Kevin Tonny Rey, "Revelasi Roh Kudus Bagi Interpreter Dalam Menafsirkan Alkitab," Jurnal Antusias 1, no. 3 (September 1, 2011): 27-36, accessed April 20, 2018, http://sttintheos.ac.id/ejournal/index.php/antusias/article/view/72/71.
}

adalah bagian dari keselamatan. Hal ini berpengaruh buruk terhadap sikap orang Kristen, karena menyebabkan mereka hanya berorientasi pada hal-hal duniawi dan berharap pada materialisme. Penganut gerakan Pentakostalisme tidak sedikit terbuai dengan pandangan jika seseorang memberikan banyak, maka Allah juga akan memberikan yang banyak juga. Ini memberikan kesan buruk terhadap ajaran Kristen, bahwa dengan memberi yang banyak akan mendapatkan lebih banyak. Orientasi mereka adalah berkat finansial dan materi.

Kelemahan yang lain dari kelompok gerakan Pentakostalisme, adanya beberapa penganut gerakan Pentakostalisme setelah dipenuhi oleh Roh Kudus merasa sombong diri, dan menilai orang yang lain yang belum mendapat anugerah baptisan Roh Kudus kurang rohani dan berdosa. Seseorang bisa menilai kerohanian sesorang hanya dari kemampuan orang lain untuk dapat berbahasa Roh atau mendapat karuniakarunia Roh yang lainnya.

\section{KESIMPULAN}

$$
\text { Setiap gelombang gerakan }
$$

Pentakostalisme adalah sebuah gerakan yang berasal dari Tuhan, melalui karya Roh Kudus-Nya. Gerakan Pentakostaklisme adalah gerakan 
gelombang Roh Kudus. Allah berdaulat sekarang ini melalui karya-karya Roh Kudus. Karunia-karunia Roh Kudus, mujizat, kesembuhan, bahasa roh, dan karya-karya-Nya yang lain masih terus menerus berlangsung dan sangat eksis di dalam dan melalui gereja-Nya, yaitu tubuh Kristus. Setiap gelombang gerakan Pentakostalisme ini murni dari Allah, namun ada pihak-pihak lain secara subyektif berusaha untuk merusak dengan ajaran dan praktek yang tidak sesuai dengan kebenaran Alkitab. Mereka hanya mencari dan menekankan ajaran dan perilaku yang bersifat subyektifitas, sensasional dan fenomenal; ajaran dan perilaku telah menyimpang dan tidak sehat.

Sekalipun ada ajaran dan perilaku kelompok gerakan Pentakostalisme yang dianggap sesat, bukan berarti bahwa secara generali setiap gelombang gerakan Pentakostalisme itu sesat dan salah. Kenyataan historis yang tidak boleh diabaikan oleh semua pihak adalah bahwa sebelum ada gelombang-gelombang gerakan Pentakostalisme yang terformulasi dengan jelas di abad ke 20, telah ada penyesatan dan kepalsuan disepanjang sejarah gereja. Jadi, adanya ajaran dan perilaku yang dianggap menyimpang dalam gerakan ini bukan berarti semua yang berada dalam gelombang-gelombang gerakan Pentakostalisme itu sesat. Demikian juga dengan adanya mujizatmujizat palsu, bukan berarti semua mujizat yang terjadi di dalam kelompok gerakan Pentakostalisme ditolak karena menganggapnya semua mujizat adalah palsu. Jadi jika ada ajaran dan perilaku yang dianggap menyimpang di dalam gerakan Pentakostalisme, bukan berarti semua ajaran dan perilaku yang berada dalam gerakan Pentakostalisme adalah sesat.

\section{DAFTAR PUSTAKA}

Alley, John Kingsley. Pewahyuan Rasuli: Reformasi Dalam Gereja. Jakarta: Metanonia, 2007.

Aritonang, Jan S. Berbagai Aliran Di Dalam Dan Di Sekitar Gereja. Jakarta: BPK Gunung Mulia, 2003.

Barrett, David B., ed. World Christian Encyclopedia. New York: Oxford University Press, 1982.

Baskoro, Haryadi. 77 Renungan Alkitabiah Tentang Akhir Zaman. Yogyakarta: Andi Offset, 2011.

Bridge, Donald, and David Phypers. Spiritual Gifts and The Church. Illinois: Inter-Varsity Press, 1973.

Burges, Stanley M. "Pemberitaan Injil Dengan Karunia-Karunia Mukjizat Dalam Gereja Mula-Mula Setelah Zaman Alkitab." In Kebutuhan Gereja Saat Ini, edited by S Gary Greig and Kevin N. Spinger. Malang: Gandum Mas, 2012.

Cornish, Rick. Lima Menit Teologi. Bandung: Pionir Jaya, 2007.

DeArteaga, William. Quenching the Spirit. Lake Mary, FL: Creation House, 
1992.

Durasoff, Steve. Bright Wind of the Spirit: Pentecostalism Today. U.S: PrenticeHall, n.d.

Forsyth, David C. "History of the Charismatic Movement." Accessed April 17, 2018. http://www.christianfallacies.com/arti cles/forsyth/historyOfCharismaticMo vement.html.

Greig, S Gary, and Kevin N. Spinger, eds. "Kebutuhan Gereja Saat Ini." Malang: Gandum Mas, 2012.

Hoekema, Anthony A. Diselamatkan Oleh Anugerah. Surabaya: Momentum, 2010.

Iverson, Dick. "Kebenaran Masa Kini.” In Tongkat Gembala. Jakarta: Lembaga Pusat Hidup Baru, 1994.

Kooij, A. Van, and Yam'ah Tsalatsa A. Bermain Dengan Api: Relasi Antara Gereja-Gereja Mainstream Dan Kalangan Karismatik Pentakosta. Jakarta: BPK Gunung Mulia, 2007.

Maiden, Mikhael. The Seven Mountains: Memuridkan Bangsa-Bangsa Dengan Strategi Tujuh Gunung. Yogyakarta: Andi Offset, 2012.

Marzuki. Metodologi Riset: Panduan Penelitian Bidang Bisnis Dan Sosial. Yogyakarta: Ekonisia, 2005.

Menzies, William W., and Robert P. Roh Kudus Dan Kuasa. Malang: Gandum Mas, 2005.

Miller, Donald E. Reinventing American Protestantism. Berkeley: University of California Press, 1997.

Murpy, Ed. "Kita Sedang Berperang." In Adu Kuasa Dengan Penghulu Kegelapan. Bandung: Kalam Hidup, 1990.

Rey, Kevin Tonny. "Revelasi Roh Kudus Bagi Interpreter Dalam Menafsirkan Alkitab." Jurnal Antusias 1, no. 3
(September 1, 2011): 27-36.

Accessed April 20, 2018.

http://sttintheos.ac.id/e-

journal/index.php/antusias/article/vie $\mathrm{w} / 72 / 71$.

Samarenna, Desti. "Analisis 1 Korintus 14:2-6 Tentang Karunia Berbahasa Roh Dan Bernubuat." DUNAMIS: Jurnal Penelitian Teologi dan Pendidikan Kristiani 2, no. 1 (November 4, 2017): 1. Accessed April 20, 2018.

http://sttintheos.ac.id/ejournal/index.php/dunamis/article/vie $\mathrm{w} / 128$.

Silalahi, Djaka Christianto. Kharismatik Bercampur Dengan Perdukunan? Yogyakarta: Andi Offset, 2001.

Soesilo, Yushak. "Pengalaman Pribadi Dengan Roh Kudus Sebagai Indikator Kualitas Pelayanan.” Jurnal Antusias 1, no. 3 (September 1, 2011): 109117. Accessed March 4, 2018. http://sttintheos.ac.id/ejournal/index.php/antusias/article/vie w/79/78.

Stearns, Robert, Chuck Pierce, and Larry Kreider. Today's Church. Yogyakarta: Andi Offset, 2013.

Susanto, Hasan. Perjanjian Baru Interlinear Yunani-Indonesia Dan Konkordansi Perjanjian Baru. Malang: SAAT, 2004.

Sutoyo, Daniel. Gerakan Pentakostalisme: Sejarah Kebangunan Rohani Yang Mewarnai Dunia Dan Injil Bagi Bangsa-Bangsa. Sukoharjo: Born Win's Publishing, 2011. . "Peran Roh Kudus Dalam Pemberitaan Injil." Jurnal Antusias 1, no. 3 (September 1, 2011): 17-26. Accessed February 25, 2018. http://sttintheos.ac.id/ejournal/index.php/antusias/article/vie $\mathrm{w} / 71 / 70$.

Tozer, A.W. Tentang Roh Kudus. Batam: 
Gospel Press, 2002.

Wagner, C. Peter. Gereja-Gereja Rasuli

Yang Baru. Jakarta: Immanuel, 1999.

Wagner, Peter C. Manfaat Karunia-

Karunia Rohani Untuk Pertumbuhan

Gereja. Malang: Gandum Mas, 1998.

. "The Third Wave?" Pastoral Renewal, 1983.

Wilson, DJ. "Pentecostal Perspectives on Eschatology." In Dictionary of Pentecostal and Charismatic Movements, edited by Stanley M. Burgess and Gary B. McGee. Grand Rapids: Zondervan Publishing House, 1998.
Wiyono, Gani. Gereja Sidang-Sidang Jemaat Allah Dalam Lintasan Sejarah 1936-2016. Malang: Gandum Mas, 2016.

"Pentakosta Dan Kharismatik." In Makalah Sahabat Awam. Bandung: Yayasan Bina Awam, n.d.

"Pentakostalisme - Gereja Pentakosta PUSTAKA BERBAHASA INDONESIA - Sejarah.sttMandala.web.id." Accessed April 17, 2018. http://sejarah.sttmandala.web.id/ind/25152408/Pentakostal_30764_sttmandala_sejarah-stt-mandala.html. 